\title{
Design and Simulation of Closed Loop Proportional Integral (PI) Controlled Boost Converter and 3-phase Inverter for Photovoltaic (PV) Applications
}

\author{
Riadh Adnan Kadhim \\ Department of Electromechanical Engineering/ University of Technology \\ Email:alazizdl@gmail.com
}

(Received 17 April 2018; accepted 14 June 2018)

https://doi.org/10.22153/kej.2019.06.001

\begin{abstract}
This research deals with the design and simulation of a solar power system consisting of a KC200GT solar panel, a closed loop boost converter and a three phase inverter by using Matlab / Simulink. The mathematical equations of the solar panel design are presented. The electrical characteristics of the panel are tested at the values of 1000 $\mathrm{W} / \mathrm{m}^{2}$ for light radiation and $25{ }^{\circ} \mathrm{C}$ for temperature environment. The Proportional Integral (PI) controller is connected as feedback with the Boost converter to obtain a stable output voltage by reducing the oscillations in the voltage to charge a battery connected to the output of the converter. Two methods (Particle Swarm Optimization (PSO) and Zeigler- Nichols) are used for tuning PI controller to enhance the overall performance of the system. The Sine Pulse Width Modulation (SPWM) technique was used to obtain a pure 3-phase in low distortion. The voltage and current output values of $\pm 14 \mathrm{~V}$ and $\pm 2.8 \mathrm{~A}$ are obtained, and the Total Harmonic Distortion (THD) value is $4.20 \%$.
\end{abstract}

Keywords: Photovoltaic systems, Boost converter, PI Controller, Inverter, PSO algorithm, Zeigler- Nichols method.

\section{Introduction}

Nowadays, photovoltaic (PV) panels are widely used to convert the solar radiation into electricity. The optimum operating point depends on environment conditions such as cell temperature and solar irradiation. K. K. and A. S. Kumar [1] presented the modeling of Photovoltaic system controlled by Maximum Power Point Tracking (MPPT) technology. They are focus on the design and simulation of PV system connected to power inverter. Matlab/Simulink results are obtained for standard operating conditions. M. F. Adnan et al [2] presented the design and simulation of a Boost converter with Proportional Integral Derivative (PID) controller to enhance the performance of the system. The objective of a Boost converter is to achieve a constant output voltage despite variations in source voltage. U. Jagadeesh and K, L. Achari [3] presented model of a buck-boost converter for Photo-Voltaic applications. They used Perturbation and Observation (P\&O) method to achieve maximum power point. K.K.Saravananet al. [4] presented the use 3-phase inverter to give higher reliability. The proposed Current Source Inverter (CSI) removes the earth leakage current, then increasing the efficiency. Y. V. Dhotre and Ponkshe V.S. [5] present open loop and closed loop controlled systems by using Matlab software. PID controller is used to reduce the oscillations in output voltage. The system used a Boost Converter to achieve fast response and reduce the hardware. K.Umadevi et al [6] presented the simulation of a PV system using Matlab. SPWM technique is used to control the operation of inverter, and PSIM (a simulation tool designed for power electronics and dynamic systems) software is used for converter topology.

A. A. Bakar et al [7] presented the design of PI controller for a boost converter using Real 
Time Interface (RTI) to achieve faster transient response which can be observed by using dSPACE RTI (an open source repository software package). G. Mühürcü et al [8] presented the design of Buck Converter which was added to discrete time PI controller. The efficiency of control process is maintained at high level by optimizing the proportional gain $\left(K_{p}\right)$ and integral gain $\left(K_{i}\right)$ in PSO algorithm.

M. Dave and S. R. Vyas [9] presented the modeling and simulation of solar inverter by using Matlab software. SPWM technique is used for the switching operation to reduce the harmonics in the output. A. M.Thu and K. S. Lwin [10] presented a method to build a pure sine wave inverter system which used operational amplifier, DC-DC converter and power MOSFETS. The Pulse Width Modulation (PWM) signal is produced by using the TL 084 and LM 339 Integrated Circuits. S. Rout [11] presented the implementation of PV Model hardware by using the Matlab/Simulink software. The P\&O algorithm for MPPT control is simulated in the MATLAB/Simulink software. The design of converter is also presented. P. Aravind and S.M.G. Kumar [12] proposed an application of PSO to set the PI controller for nonlinear process. The tuning values of the controller are tested in level control system. They prove that PSO-PI controller yield good results than gain scheduling method.This paper presents the design and Simulation of a PV power system consist of solar panel type KC200GT, DC-DC boost converter for interface between $\mathrm{PV}$ panel and 3-phase inverter. The PI controller is used to regulate output voltage of Boost converter to get the fast transient response by adjusting the value of proportional gain ( $\left.K_{p}\right)$ and integral gain ( $K_{i}$ ) accordingly. The sinusoidal ac output voltage is achieved by inverted Boost converter voltage via inverter by using SPWM technique which gives a pure sine wave with low THD.

\section{System Design}

The block diagram of the proposed system design is shown in fig. 1. KC200GT Solar panel is used for PV module. The Boost DC-DC converter with PI controller is used to adjust the output voltage. The output of battery is fed to 3phase voltage source inverter. The filter is used to achieve a pure sine wave.

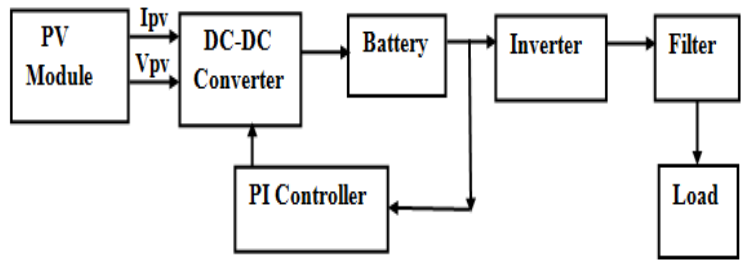

Fig. 1. The proposed system design.

\section{PV Cell}

The main part of PV module is a PV cell. There are different types of PV module depending on the cells compose the module itself. Silicon Single-diode PV cells is applicable to simulate in this paper. The PV model consists of a photocurrent source, series resistance, nonlinear diode and shunt resistance as shown in Fig. 2[13].

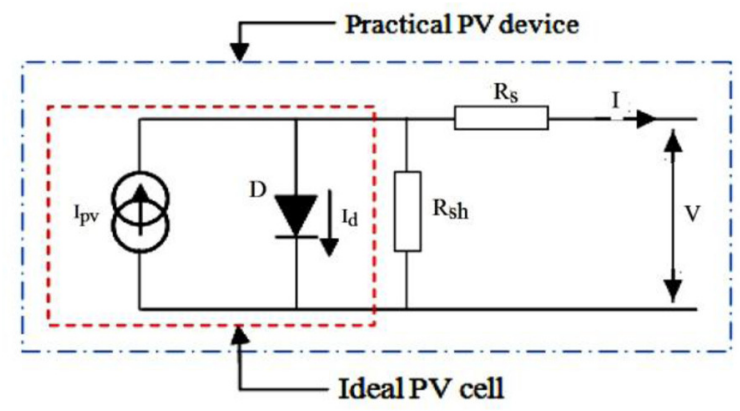

Fig. 2. PV cell model.

The main parameters that characterize a photovoltaic panel are open circuit voltage $\left(V_{o c}\right)$, short circuit current $\left(I_{S C}\right)$, maximum power point $\left(P_{\max }\right)$ and efficiency $(\eta)[14]$.The mathematic equation for the voltage and current can be described as [13]:

$\mathrm{I}=\mathrm{I}_{\mathrm{ph}}-\mathrm{I}_{\mathrm{s}}\left[\exp \left\{\frac{\mathrm{q}\left(\mathrm{V}+\mathrm{IR}_{\mathrm{s}}\right.}{\mathrm{AkT}}\right\}-1\right]-\left[\frac{\mathrm{V}+\mathrm{IR}_{\mathrm{s}}}{\mathrm{R}_{\mathrm{sh}}}\right]$.

where: $I_{p h}$ is photocurrent; $I_{s}$ is diode saturation current; $q$ is electron charge $(1.602 \times$ $10-19 \mathrm{C} ; A$ is PN junction ideality factor; $k$ is Boltzmann's constant $(1.381 \times 10-23) ; T$ is cell temperature.

Photocurrent $\left(\mathrm{I}_{\mathrm{ph}}\right)$ is the function of cell temperature and solar radiation can be described as:

$\mathrm{I}_{\mathrm{ph}}=\left[\frac{\mathrm{G}}{\mathrm{G}_{\mathrm{ref}}}\right]\left[\mathrm{I}_{\text {ph.ref }}+\mathrm{C}_{\mathrm{T}}\left(\mathrm{T}-\mathrm{T}_{\text {ref }}\right)\right]$

where: $G$ is the real solar radiation $(\mathrm{W} / \mathrm{m} 2) ; G_{\text {ref }}$ $, T_{\text {ref }}, I_{p h \text {,ref }}$ are the solar radiation, cell 
absolute temperature, photocurrent respectively in STC; $C_{T}$ is the temperature coefficient $(\mathrm{A} / \mathrm{K})$. Diode saturation current $I_{S}$ varies with the cell temperature as:

$I_{S}=I_{S} r e f \times\left(\frac{T}{T_{r e f}}\right)^{3} \times \exp \left[\frac{q \times E_{g}}{A \times K} \times\left(\frac{1}{T_{r e f}}-\frac{1}{T}\right)\right]$

where: $I_{s, r e f}$ the diode saturation current (A) ; $E_{g}$ is the band-gap of the cell semiconductor $(\mathrm{eV})$.

PV panel is composed of cells tied in parallel and series. The equivalent circuit of PV array can be described as illustrated in Fig. 3[13].

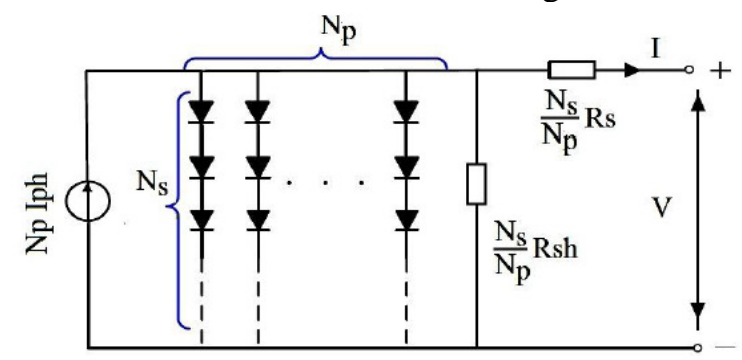

Based on the equivalent circuit of a PV module, its characteristic equation is given as follows [15]

$I=N_{p} I_{p h}-N_{p} \times I_{s} \times\left[\exp \left(\frac{q}{A \times K \times T}\left(\frac{V}{N_{s}}+\right.\right.\right.$

$\left.\left.\left.\frac{\mathrm{I} \times \mathrm{R}_{\mathrm{s}}}{\mathrm{N}_{\mathrm{p}}}\right)\right)-1\right]-\frac{\mathrm{N}_{\mathrm{p}}}{\mathrm{R}_{\mathrm{sh}}}\left(\frac{\mathrm{V}}{\mathrm{N}_{\mathrm{s}}}+\frac{\mathrm{I} \times \mathrm{R}_{\mathrm{s}}}{\mathrm{N}_{\mathrm{p}}}\right)$

where: $N_{s}$ and $N_{p}$ are series and parallel cell numbers respectively.

Matlab/Simulink is used to implement the mathematical equation (4), as shown in the fig. 4. The parameters used in Simulink are listed in Table 1[15].

Fig. 3. PV model.

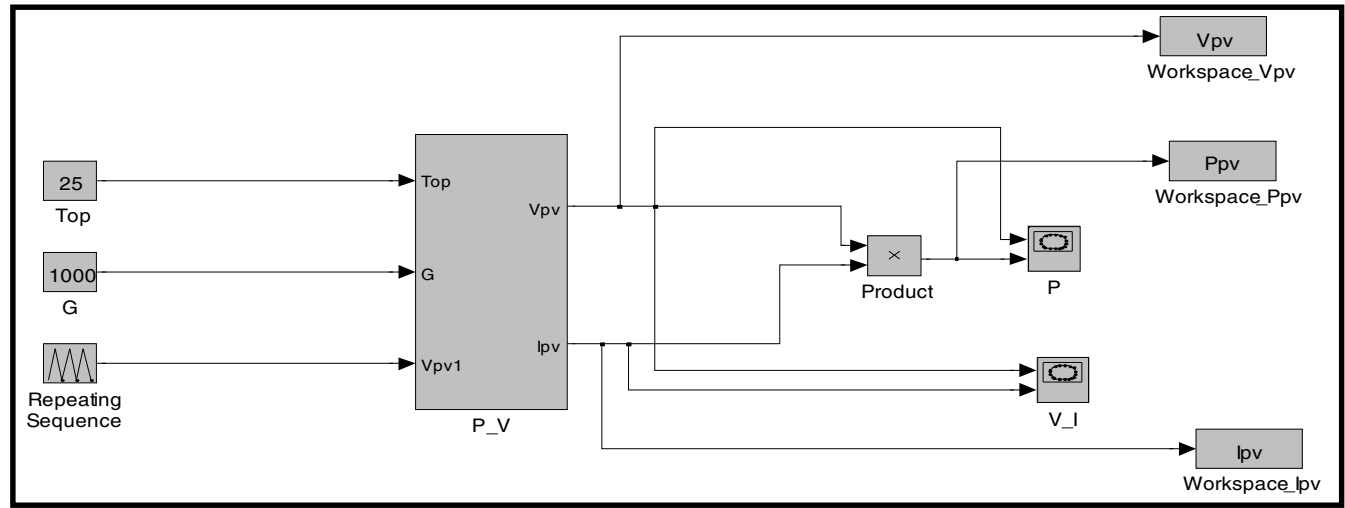

Fig. 4. Simulink Model of PV cell in MATLAB.

Table 1,

KC200GT parameters values for solar module at $1000 \mathrm{~W} / \mathrm{m}^{2} \mathrm{~W} / \mathrm{m}^{2}, 25^{\circ} \mathrm{C}$.

\begin{tabular}{ll}
\hline Parameter & Value \\
\hline $\mathrm{G}_{\text {ref }}$ & $1000 \mathrm{~W} / \mathrm{m}^{2}$ \\
$\mathrm{~T}_{\mathrm{ref}}$ & $298 \mathrm{~K}$ \\
$\mathrm{~N}_{\mathrm{s}}$ & 24 \\
$\mathrm{I}_{\mathrm{sc}}$ & $8.21 \mathrm{~A}$ \\
$\mathrm{~V}_{\mathrm{oc}}$ & $32.9 \mathrm{~V}$ \\
$\mathrm{I}_{\mathrm{m}}$ & $7.61 \mathrm{~A}$ \\
$\mathrm{~V}_{\mathrm{m}}$ & $26.3 \mathrm{~V}$ \\
$\mathrm{~K}_{\mathrm{i}}$ & $0.0009 \mathrm{~A} / \mathrm{K}$ \\
$\mathrm{K}_{\mathrm{v}}$ & $-0.123 \mathrm{~V} / \mathrm{K}$ \\
$\mathrm{E}_{\mathrm{g}}$ & $1.237 \mathrm{eV}$ \\
$\mathrm{R}_{\mathrm{s}}$ & $0.221 \Omega$ \\
$\mathrm{R}_{\mathrm{sh}}$ & $415.3 \Omega$ \\
$\mathrm{A}$ & 1.35 \\
\hline
\end{tabular}

\section{Boost DC-DC Converter}

The DC-DC boost converter is a switching step up converter. Fig.5 shows the electronic circuit of the converter [16].

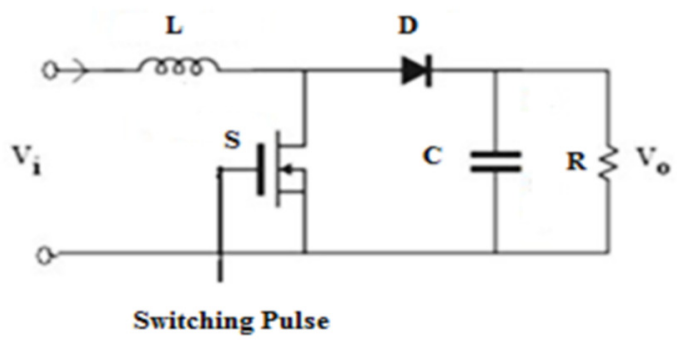

Fig. 5. Boost Converter Circuit. 
There are two modes of operation the Boost converter. Mode 1 begins at $t=0$ and ends at $t=t_{\text {on }}$ when the transistor is switched $\mathrm{ON}$. The inductor current $i_{L(t)}$ increased linearly and the voltage measured on the inductor is $V_{i}$. When the transistor switched OFF, Mode 2 is begin at $t=t_{o n}$ and ends at $t=t_{s}$. The $i_{L(t)}$ decrease until the transistor is turned $\mathrm{ON}$ to begin the next cycle. In this period, the voltage across the inductor is become $V_{i}-V_{o}$. In steady state, time integral of the inductor voltage over one time period must be zero as follows [16]:

$\mathrm{V}_{\mathrm{i}} \mathrm{t}_{\mathrm{on}}+\left(\mathrm{V}_{\mathrm{i}}-\mathrm{V}_{\mathrm{o}}\right) \mathrm{t}_{\mathrm{off}}=0$

where, $V_{i}$ : The input voltage, $V_{o}$ : The average output voltage, $t_{o n}$ : The switching ON time, $t=t_{\text {off }}$ : the switching OFF time.

Dividing both sides by $T_{S}$ and rearranging items yield.

$\frac{\mathrm{V}_{\mathrm{o}}}{\mathrm{V}_{\mathrm{i}}}=\frac{\mathrm{T}_{\mathrm{s}}}{\mathrm{t}_{\mathrm{off}}}=\frac{1}{1-\mathrm{D}}$

where $T_{S}$, The switching period, D : The duty cycle.

Switch is triggered by the pulse which is generated by PI controller using PWM technique. $V_{i}$ is the DC input voltage taken from the PV module. When switch turns ON the current of inductor is increases, and the relationship between $V_{i}$ and $I_{S}$ as following [16]:

$\mathrm{V}_{\mathrm{i}}=\mathrm{L} \frac{\mathrm{dI}_{\mathrm{s}}}{\mathrm{dt}}$

Using Laplace Transformation,

$\mathrm{V}_{\mathrm{i}}(\mathrm{s})=\mathrm{L} \mathrm{s} \mathrm{I}_{\mathrm{s}}(\mathrm{s})$

From fig.5. , $V_{O}$ can be given as:

$\mathrm{V}_{\mathrm{o}}(\mathrm{s})=\mathrm{I}_{\mathrm{s}}(\mathrm{s}) \mathrm{R}$

$\frac{\mathrm{V}_{\mathrm{o}}(\mathrm{s})}{\mathrm{V}_{\mathrm{i}}(\mathrm{s})}=\frac{\mathrm{R}}{\mathrm{Ls}}$

Equation (10) is the basic Laplace transformation equation of the boost converter.

To calculate the capacitor and Inductor of the converter, the following basic equations must be used [6],

$\mathrm{C}=\frac{\mathrm{I}_{\mathrm{o}} \mathrm{D}}{\mathrm{f} \Delta \mathrm{V}_{\mathrm{o}}}$

$\mathrm{L}=\frac{\mathrm{V}_{\mathrm{i}} \mathrm{D}}{\mathrm{f} \Delta \mathrm{I}_{\mathrm{l}}}$

where: $f$ is switching frequency and $I_{o}$ is Output current.

\section{Regulated Closed Loop Circuit}

The battery in solar system is used to store the power to fill the energy requirements at night or during period of low solar irradiation. Battery storage should be controlled to avoid overcharging or frequent deep discharging. Switch mode DC - DC converters permit the charge current to be decreased continuously to maintain the battery voltage at a defined value. In open loop system, the output from PV panel is the input of boost converter. The converter output is not constant, and it's not appropriate for battery charging. This is the disadvantage of the system [5]. To overcome this problem, closed loop system with PI controller as feedback is used. The output of the PI controller is writing as follows [17]:

$u_{a}(t)=k_{c}\left(e(t)+\frac{1}{\tau_{I}} \int_{0}^{t} e(t) d x\right)+u_{a b} \ldots$

where: $u_{a}(t)$ is controller output, $K_{c}$ is the controller proportional gain, $e(t)$ is the error signal, $\tau_{I}$ the integral time constant, $u_{a b}$ is the bias signal of the actuator.

The transfer function $G_{c}(s)$ of the PI controller can be writing as follows:

$G_{c}(s)=k_{c}\left(1+\frac{1}{\tau_{I} s}\right)$

In the present mode, the PI controller presents the advantage of eliminating the deviation between the output and the set point. The error signal is generated by comparing $\left(V_{\text {ref }}\right)$ with the battery output voltage. This error signal is fed to PI controller which generates the control signal for changing the time period for turn $\mathrm{ON}$ and OFF to achieve the constant output voltage $\left(V_{o}\right)$. Fig. (6) Shows the block diagram of closed loop Boost Converter. The principle of that is when a load change, a new controller output is produced, and the error is produced also. This operation is repeated continuously and the controller output is provided through a sum of proportional plus integral action until the error became zero. 


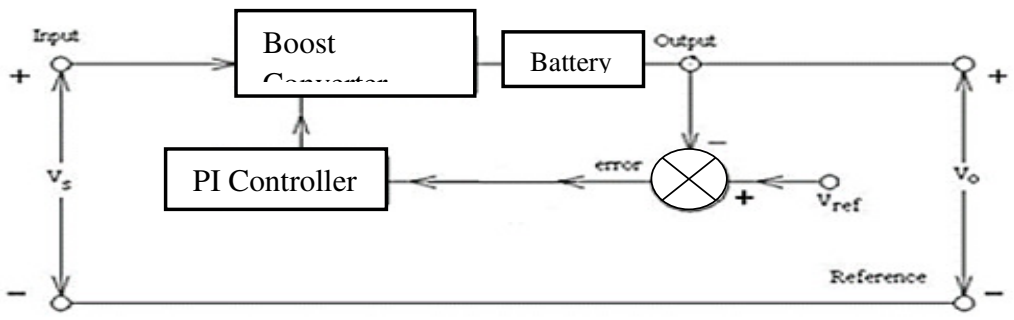

Fig. 6. Block Diagram of closed loop Boost Converter.

\section{Simulink of Closed Loop System}

Fig.7 show the Simulink circuit of PV panel connected to boost converter with PI controller and battery to maintain constant output voltage. Simulation studies is carried out by using following data: $\mathrm{L}=2.2 \mathrm{mH}, \mathrm{C}=600 \mu \mathrm{F}$.

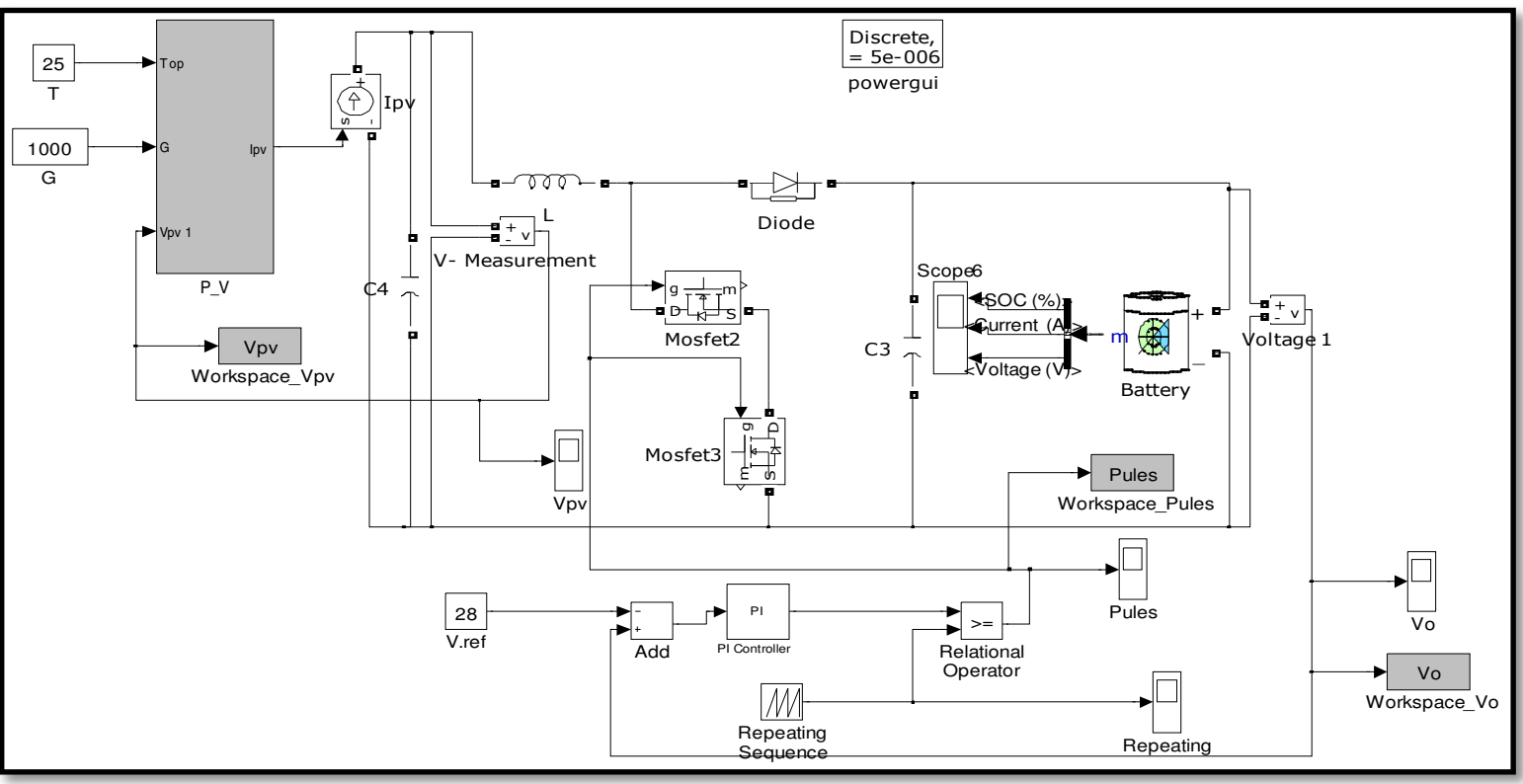

Fig.7. Closed loop Simulink model.

\section{Particle Swarm Optimization(PSO)}

PSO algorithm is initialized with a number of random particles with random distribution that is assigned to random velocity. The particles are a swarm moving in the search space looking for optima by updating the particles positions during the generations. Each particle moves in the search space with an adaptive velocity and adjusts its trajectory towards its best solution (fitness) [18]. The fitness function is used to determine the best fitting solution is achieved by evaluates the performance of particles. All possible sets of controller parameter values are adjusted so as to minimize the error criterion. The index parameters most often used are [19]:
Integral of the Absolute Error $(I A E)=$ $\int_{0}^{\infty}|e(t)| d t$

Integral of the Square Error $(I S E)=$

$\int_{0}^{\infty} e^{2}(t) d t$

Integral of the Time -Weighted Absolute

Error $(I T A E)=\int_{0}^{\infty} t|e(t)| d t$

Mean Square Error $(M S E)=\int_{0}^{\infty} t e^{2}(t) d t$

Where $e(t)$ is the deviation (error) of the response from the desired set point.

\section{Ziegler-Nichols Method}

In this method, the ultimate gain of a proportional controller and the ultimate period of oscillation are used to represent the dynamic 
characteristic of the process. The following procedure is used to determine the ultimate gain and period:

The steps for tuning a PID controller as follows:[20]:

1. Reduce the integrator and differentiator gains to 0 .

2. Increase $K p$ from 0 to some critical value $K c r=K p$ at which sustained oscillations occur.

3. Record the value $\mathrm{Kcr}$ and the corresponding period of sustained oscillation, $\mathrm{Pcr}$

4. The controller gains are now specified as follows:

Table 2,

Ziegler Nichols Method

\begin{tabular}{llll}
\hline PID type & $\boldsymbol{K}_{\boldsymbol{p}}$ & $\boldsymbol{T}_{\boldsymbol{i}}$ & $\boldsymbol{T}_{\boldsymbol{d}}$ \\
\hline P & $0.5 K_{c r}$ & $\infty$ & 0 \\
PI & $0.45 K_{c r}$ & $\frac{P_{c r}}{1.2}$ & 0 \\
PID & $0.6 K_{c r}$ & $\frac{P_{c r}}{2}$ & $\frac{P_{c r}}{8}$ \\
\hline
\end{tabular}

\section{Power Part}

\subsection{Inverter Circuit}

The main component of the power part is the six power MOSFETs, six freewheeling diodes, one with each MOSFET is used for the bypass of back e.m.f. The schematic diagram of the power part is shown in Fig.8[21]. When the generated power is transmitted to the load, it is necessary to use the inverters with three phase output.

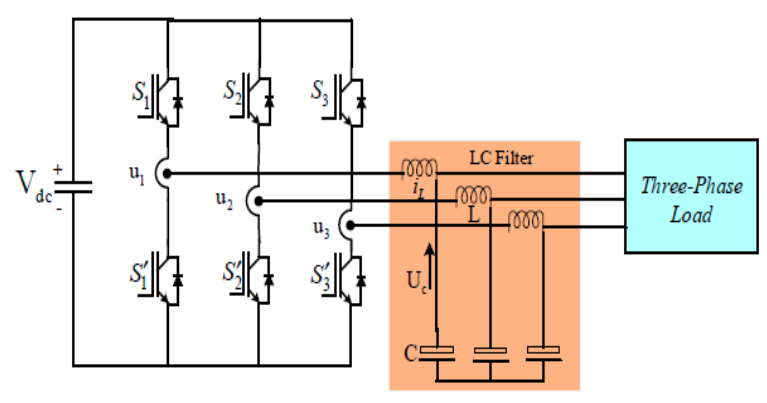

Fig. 8. Schematic of power part of inverter.

\subsection{Sinusoidal Pulse Width Modulation (SPWM)}

SPWM technique is used to generate $\mathrm{AC}$ current with low harmonic distortion. The multiple numbers of different widths pulses are generated with this modulation technique.
Six switching pulses is generated from discrete PWM generator. These pulses are used for switching the MOSFET transistors in the power stage. The reference signal frequency is used to determine the inverter output, and the speed of switching the inverter to determine ON and OFF time period. Switching frequency affects the output of the inverter that results the harmonics on the output [2]. SPWM technique is depending on comparing a high-frequency carrier with a low-frequency sinusoidal signal. The carrier has a constant period, this leads to constant switching frequency. The instant of switching is determined from the crossing of the modulating signal and carrier.

\subsection{LC Filter}

The design of an electric system requirement the reduction of the harmonic, therefore, a filter connected to output is used for this purpose. This filter topology is relatively easier to design and it has substantially sophisticated damping behavior (the value of inductance affected on cut-off frequency, but the value of capacitance affected on the output voltage quality) [21].

\section{Total Harmonic Distortion (THD)}

The harmonic content of a waveform is measured by THD index which is applied to either current or voltage. THD is the summation of all the harmonic frequency currents to the fundamental [22]. The THD can be calculated by the following equation.

$\mathrm{THD}=\frac{\sqrt{\sum_{\mathrm{h}=2}^{\mathrm{n}} V_{h}{ }^{2}}}{\mathrm{~V}_{1}}$

where: $\mathrm{n}$ is the maximum harmonic order, $\mathrm{h}$ is the harmonic order, and $\mathrm{V}_{\mathrm{h}}$ is $\mathrm{h}$ amplitude.

\section{Simulink of System Design}

The basic components of the Simulink model for the system are the PV cell represented by PV3, the DC-DC converter, inverter and LC filters show in fig.9. The DC-DC converter model consists of two static switch, two inductors (L1, L2), Diode D, and capacitors (C3, C4). In DC$\mathrm{AC}$ inverter there are four MOSFET transistors switches. LC filter is connected with the load to maintain a constant output voltage decrease output ripple 


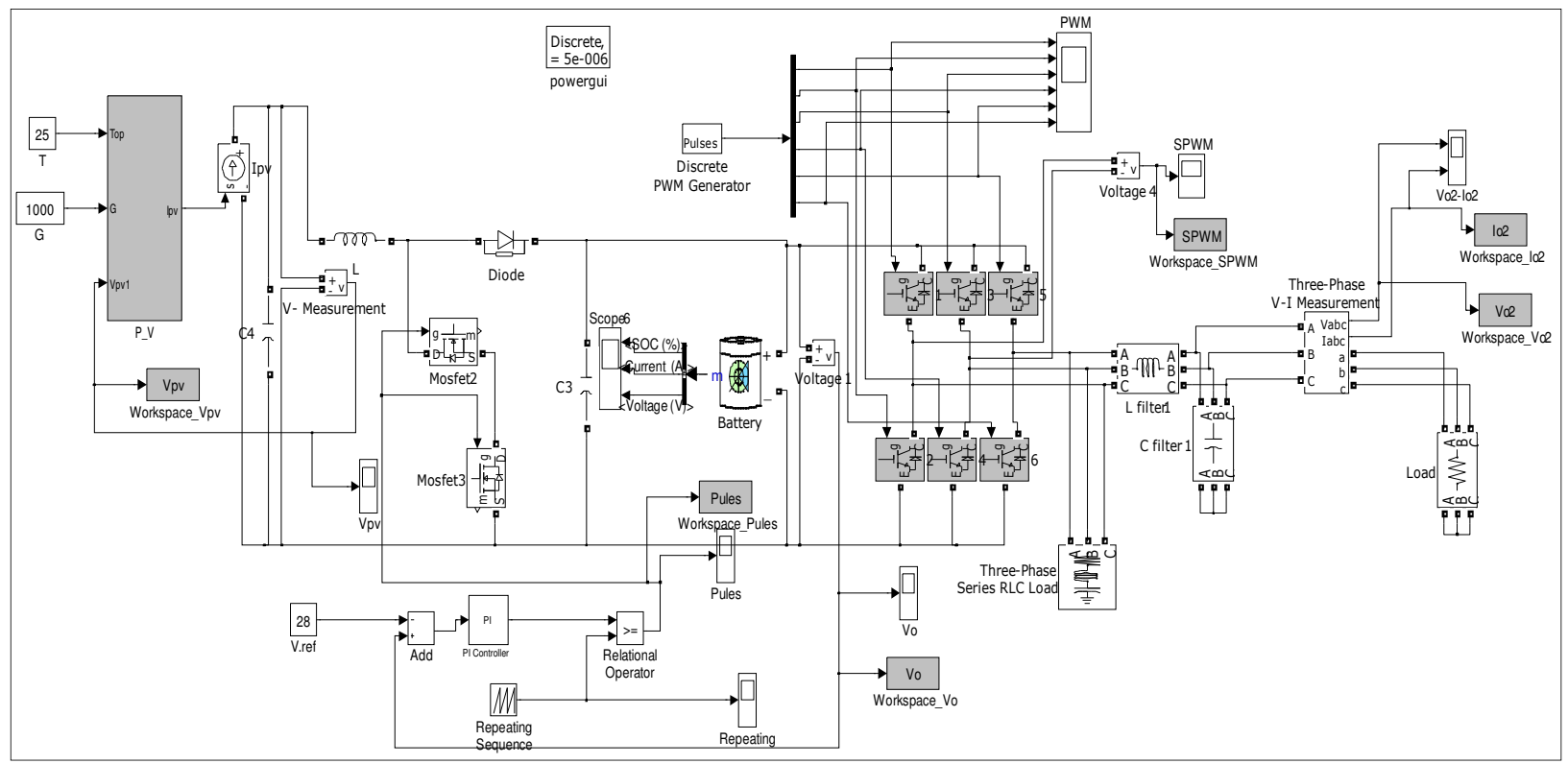

Fig. 9. Simulink model for the system Design.

\section{Results and Discussion}

Matlab/Simulink software are used for tested the system. The simulation results of electric characteristics of the PV module at temperature of $25^{\circ} \mathrm{C}$ and irradiation of $1000 \mathrm{~W} / \mathrm{m} 2$ are shown in fig.10. The component values used in simulation are $R_{S}=0.221 \Omega, R_{s h}=415.3 \Omega$. The results are $V_{o}=8.2 \mathrm{~V}, P_{m}=250 \mathrm{~W}$.

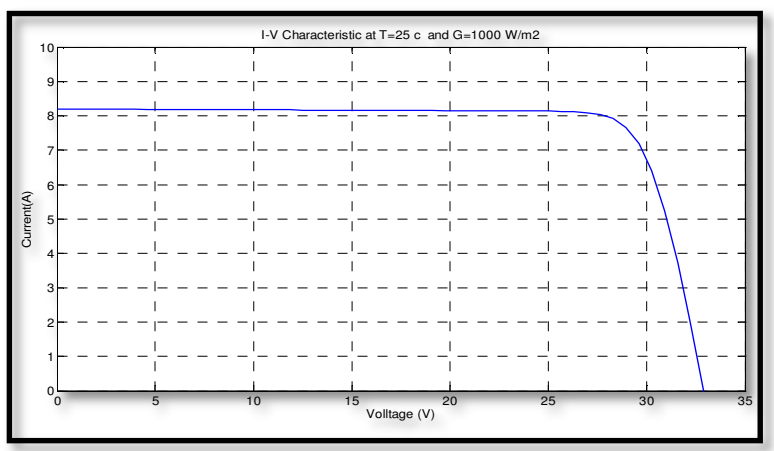

(a)

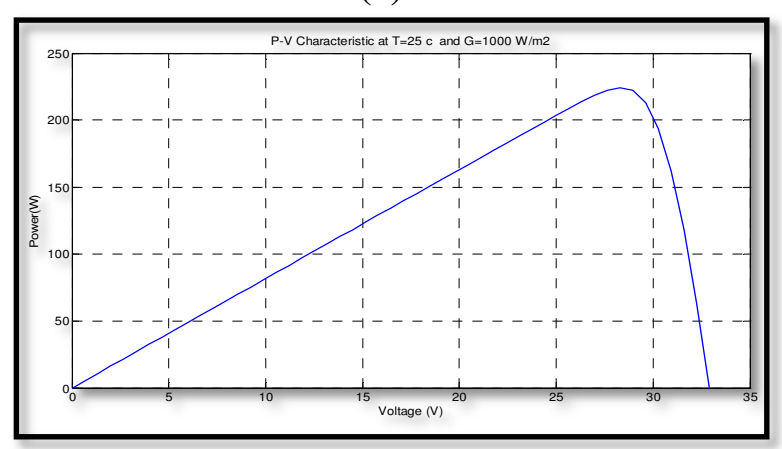

(b)

Fig. 10. Electric characteristics of PV module.
A PV panel is connected to the step up converter to increase the voltage from $20 \mathrm{~V}$ to $28 \mathrm{~V}$ which is necessary to supply the inverter to generate the required ac output voltage. The PV voltage and current are shown in Fig. 11. The voltage $\left(V_{p v}\right)$ equal to $20 \mathrm{~V}$ and it is remain stable after $0.2 \mathrm{sec}$ as shown in fig 11a. The current is equal to $8.2 \mathrm{~A}$ as shown in fig. $11 \mathrm{~b}$.

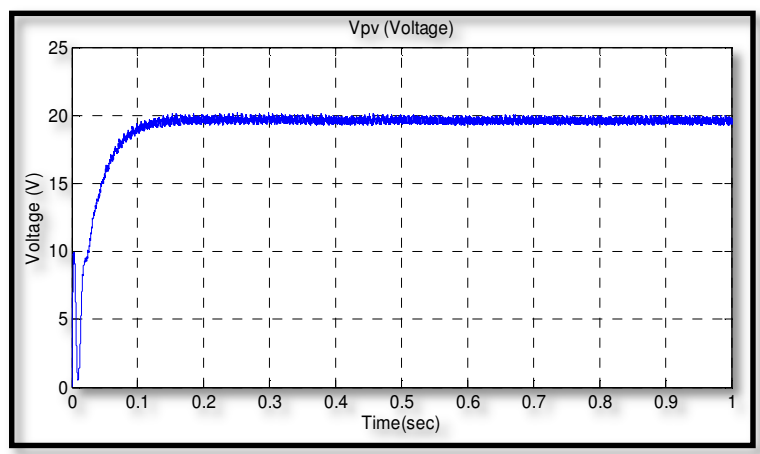

(a)

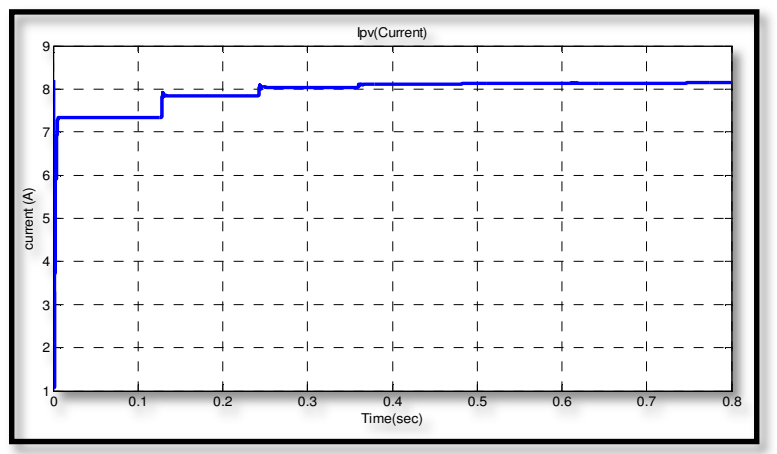

(b)

Fig. 11. Vpv and Ipv for PV panel. 
There is some distortion from $0.0 \mathrm{sec}$ to 0.2 sec, this distortion can be reduced by connect the PV panel to DC-DC Boost converter which is controlled by PI controller. Analysis of boost converter is performed in continuous mode of operation with switching $1 \mathrm{KHz}$. Switching pulse generated from PI controller is used to control the operation of Boost converter which is the output voltage is $28 \mathrm{~V}$ as shown in Fig. 12.This output voltage is obtained at the $K_{p}=0.001125$ and $K_{i}=0.092270$.

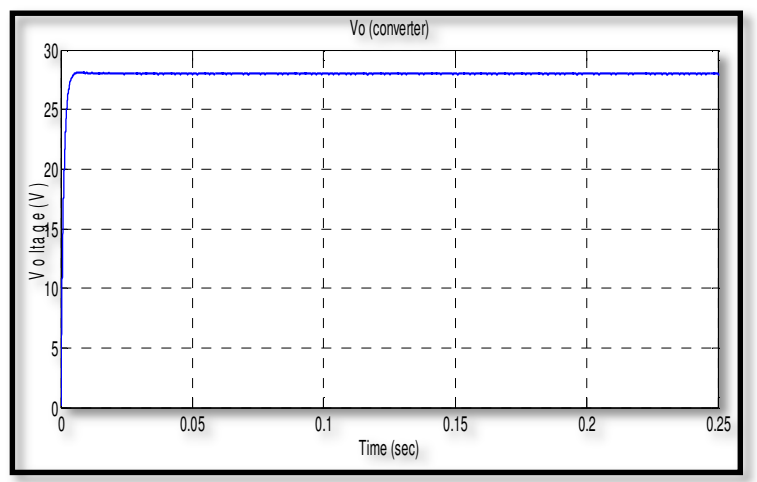

The parameters used in PSO algorithm is listed in table (3). Dynamic performance analysis of Boost converter with different types of controller is shown in table (4). It is clear that the advantage of PSO-PI algorithm is reducing of settling time, Peak time and the steady state error when compared with other three methods (Ziegler-Nichols-PI(ZN-PI), Genetic Algorithm Fractional Order PI (GA-FOPI), Queen Bee assist Genetic Algorithm(QBGA)-FOPI.

Table 3,

PSO parameters

\begin{tabular}{ll}
\hline Parameters & Values \\
\hline Population size & 49 \\
Numbers of iterations & 50 \\
Inertia weight $(\mathrm{W})$ & 0.9 \\
Cognitive coefficient $\left(C_{1}\right)$ & 0.9 \\
Social coefficient $\left(C_{2}\right)$ & 0.12 \\
\hline
\end{tabular}

Fig. 12. Converter output.

Table 4,

Dynamic performance analysis of Boost converter

\begin{tabular}{lllll}
\hline Specification & \multicolumn{2}{c}{ Present works } & \multicolumn{2}{c}{ Previous works(reference 23) } \\
& PSO-PI & ZN-PI & GA-FOPI & QBGA-FOPI \\
\hline Rise time(s) & 0.3441 & 0.85 & 0.218 & 0.065 \\
Peak time(s) & 0 & 0 & 0.3755 & 0.1098 \\
Setting time(s) & 0.7028 & 0.95 & 0.3755 & 2.9883 \\
$K_{p}$ & 0.001125 & 0.00765 & 0.2824 & 0.3685 \\
$K_{i}$ & 0.092270 & 0.04172 & 10.2315 & 34.0936 \\
$I S E$ & 0.102 & 0.2158 & -0.43 & 0.15 \\
\hline
\end{tabular}

The typical discharge characteristics of nickel cadmium battery can be separated into three areas as shown in fig.13. The first area is the area above the nominal value that represents the overshoot of battery voltage. The voltage is slightly changed in the nominal area which represents the second area. When the nominal capacity of battery power is discharged, it is followed by the third area of operation in which the battery voltage decreases very fast.

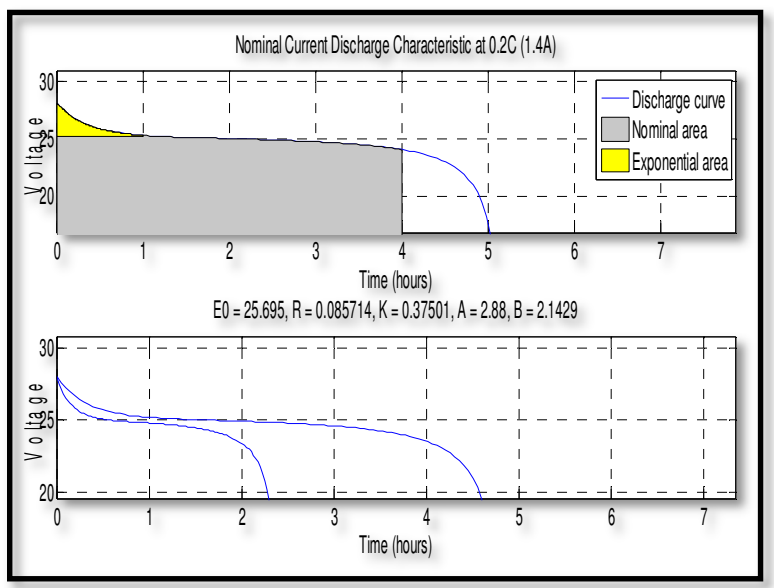

Fig. 13. Battery charging current. 
Fig.14 shows the switching signals (S1, S2, S3, S4, S5, and S6) used to drive the MOSFET transistors to regulate the inverter output voltage. It is SPWM signals. The characteristic of SPWM generator used in the Simulink design as follows: Modulation index $=0.8$; Carrier frequency $=1080$; $\mathrm{f}=50 \mathrm{~Hz}$; Phase difference $=120$.
The non-sinusoidal output signal which comes from the inverter is connected after the DC converter. The DC output voltage from the inverter is converted to AC. The value of the output voltage is $28 \mathrm{~V}$ in square wave. This is illustrated in fig. 15 .

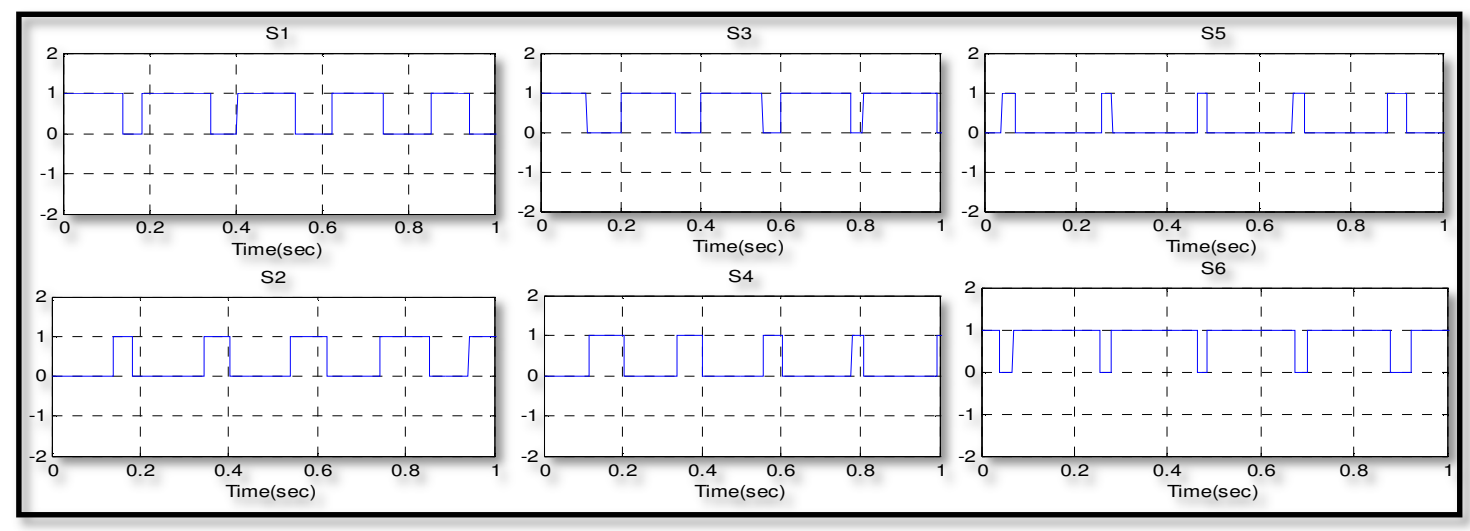

Fig. 14. Switching Signals.

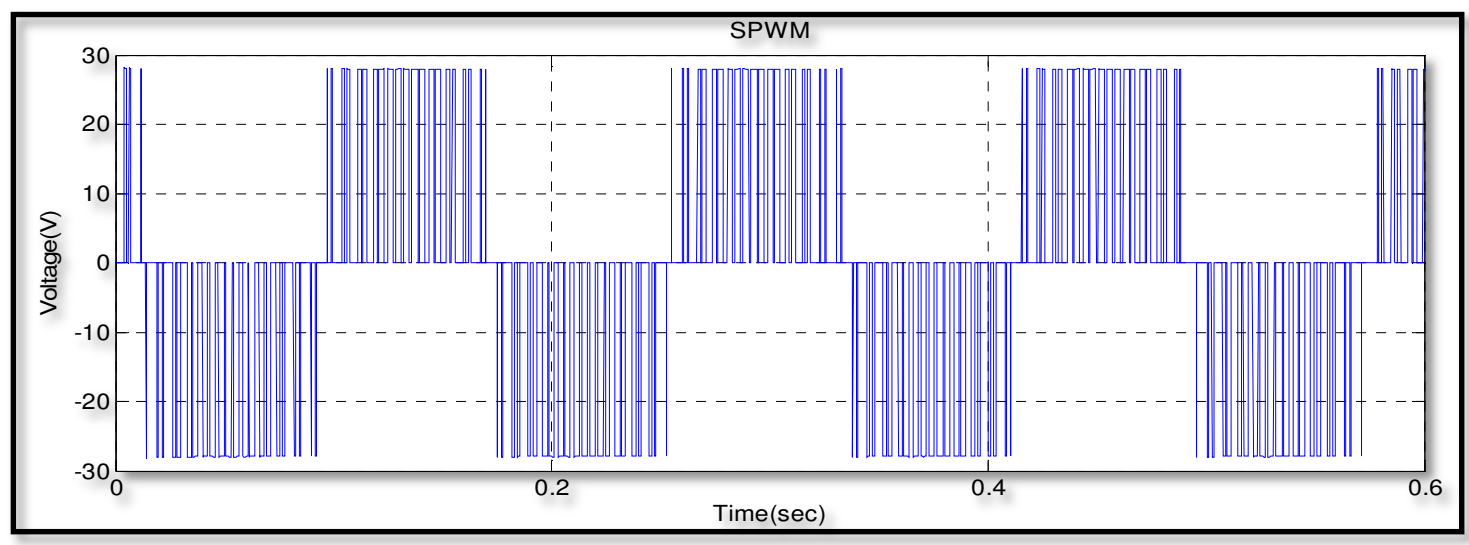

Fig. 15. Outputs from inverter voltage before filters.

The voltage and current injected into load. The sinusoidal output which comes from the inverter is connected with the filter. The elimination of the harmonic components from the output for the supply to the local load is achieved by the capacitor in the filter circuits as illustrated in fig.16. As it can be seen, the voltage and current are in phase which means the whole system operates at unity power factor with no reactive power exchange. Fig. 17 shows the THD curve. The percentage value of THD is $4.20 \%$. 


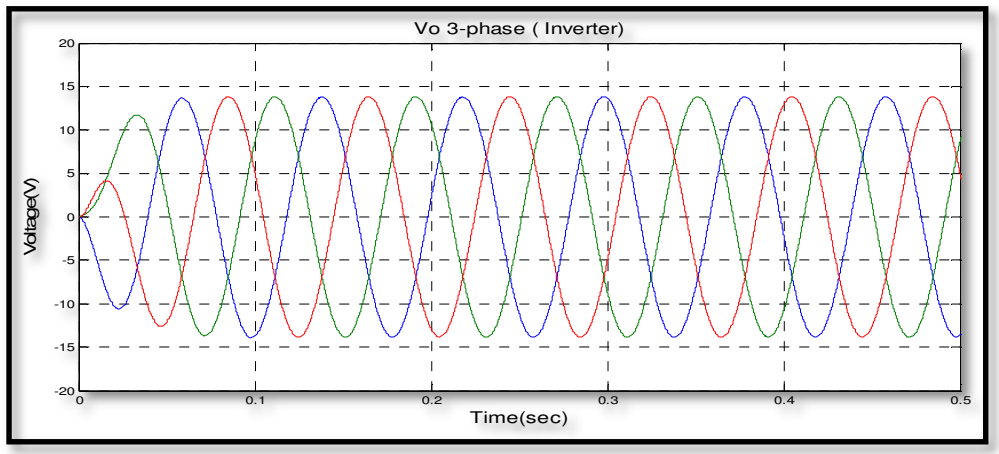

(a): Load voltage

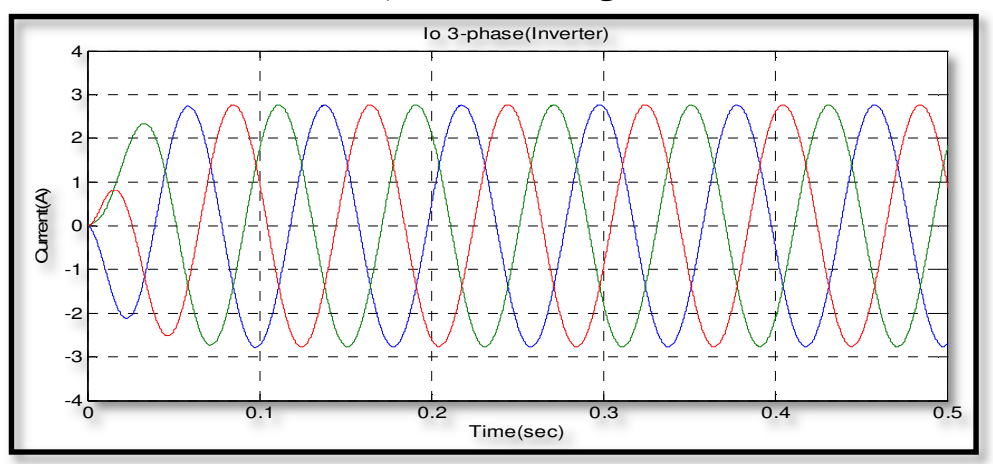

(b): Load current

Fig. 16 (a) Load Voltage, (b) Load current.

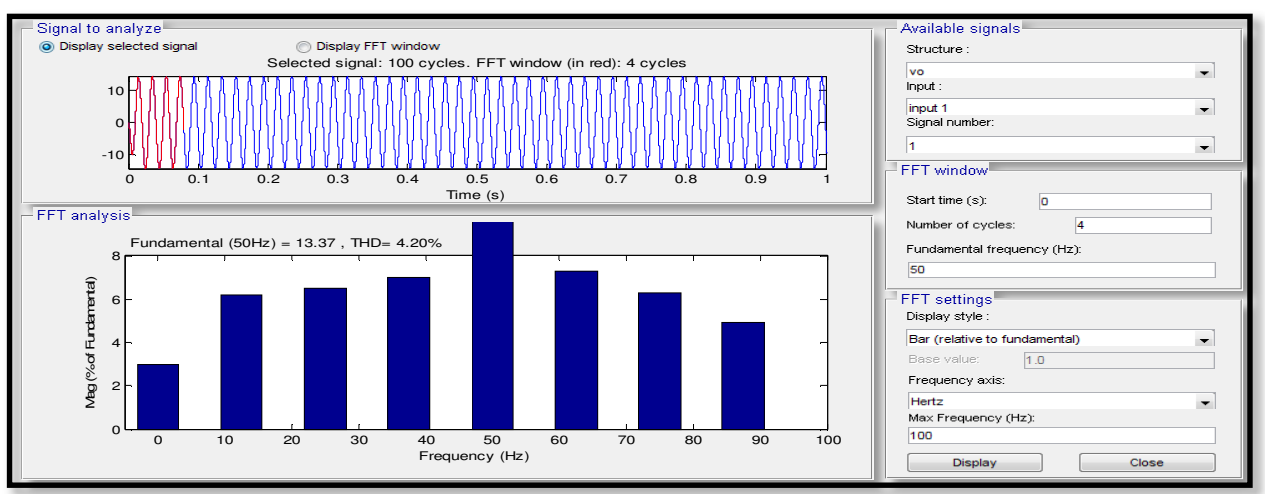

Fig. 17. THD window.

\section{Conclusion}

A complete Matlab/Simulink of PV module and closed loop Boost converter connected to 3phase inverter are carried. The electrical characteristics (P-V and I-V curves) are achieved for KC200GT solar module. The output voltage $V_{o}$ of $\mathrm{PV}$ module is equal to $8.2 \mathrm{~V}$, and the maximum power $P_{m}$ is equal to $250 \mathrm{~W}$. The oscillation in output voltage is reduced by connect a PI controller as a feedback in dc-dc converter. The boost converter increases the voltage from $20 \mathrm{~V}$ to $28 \mathrm{~V}$. Particle Swarm Optimization (PSO) and Zeigler Nichols method are used for tuning PI controller. The response of PSO gives a better performance as compared to
Ziegler and Nichols methods which helps to overcome the problem of overshoot \& settling time. SPWM technique is used with inverter to generate sinusoidal voltage and current with low harmonic distortion. The output voltage and current obtained are $\pm 14 \mathrm{~V}$ and $\pm 2.8 \mathrm{~A}$ respectively, and their signals are in phase with percentage value of THD is $4.20 \%$.

\section{References}

[1]K. Kirubasankar, A. Senthil Kumar, "Inverter Power Stage Connected with PV-Grid", Circuits and Systems, Vol.7 Issue 13, pp. 4113-4123, 2016. 
[2]Mirza Fuad Adnan, Mohammad Abdul Moin Oninda, Mirza Muntasir Nishat, Nafiul Islam," Design and Simulation of a DC - DC Boost Converter with PID Controller for Enhanced Performance", International Journal of Engineering Research \& Technology (IJERT), Vol. 6, Issue 09, pp. 2732, 2017.

[3]U. Ajagadeesh, K. Lokesh Achari,"A BuckBoost Based DC/AC Converter for Residential PV Application by using MPPT ", International Journal of Advanced Computational Engineering and Networking, Vol. 2, Issue 11, pp. 87-90, 2014.

[4]K. K.Saravanan, N. Stalin, T. Sree Renga Raja, " Design and Investigation of Grid connected Current Source Inverter for Photovoltaic System", International Journal of Advanced Engineering Technology, Vol. 7, Issue 2, pp. 280-284, 2016.

[5] Yogini V Dhotre, Ponkshe V.S., "Simulation of Closed Loop Controlled Boost Converter for PV System" International Journal on Recent and Innovation Trends in Computing and Communication, Vol. 2, Issue 6, pp.1412-1416, 2014.

[6]K.Umadevi, P.Nalandha MADEVI, C. Chenn Kesavan, "Modelling of Photovoltaic System with Converter Topology for Grid fed Operations", International Journal of Engineering and Technology (IJET), Vol. 6 Issye 5 , pp. 2392-2400, 2014.

[7]A. A. Bakar, W. M. Utomo, T. Taufik, S. Aizam and Jumadril", DC/DC Boost Converter with PI Controller using Real-Time Interface", ARPN Journal of Engineering and Applied Sciences, Vol. 10, Issue 19, pp. 9087-9082, 2015.

[8]Gülçin Mühürcü, Ercan Kose, Aydin Muhurcu, Ali Kuyumcu," Parameter Optimization of PI Controller by PSO for Optimal Controlling of a Buck Converter's Output", IEEE, DOI: 10.1109/IDAP.2017.8090234, 2017

[9]Maulik Dave, Sanjay R. Vyas," Simulation and Modeling of Single Phase DC-DC Converter of Solar Inverter", International Research Journal of Engineering and Technology (IRJET), Vol. 02, Issue 09, Dec.pp.2225-2230, 2015.

[10] Aye Myat Thu, Kyaw Soe Lwin," Design and Implementation of Solar inverter for Pure Sine Wave Inverter", International Journal of Scientific Engineering and Technology Research, Vol.03, Issue 08, pp. 1293-1297, May. 2014.
[11] Smitanjali Rout," Mathematical Modelling of Grid Connected Photovoltaic System using Matlab/Simulink and Hardware Implementation", International Journal of Computer Applications (0975 - 8887), International Conference on Emergent Trends in Computing and Communication (ETCC 2015).

[12] P.Aravind, S.M.GirirajKumar," Optimal Tuning of PI Controller using Swarm Intelligence for a Nonlinear Process", International Journal of Advanced Research in Electrical,Electronics and Instrumentation Engineering, Vol. 2, Issue 12,pp 5949-5958, 2013

[13] E. Benkhelil and A. Gherbi, "Modeling and simulation of grid-connected photovoltaic generation system", Revue des Energies Renouvelables SIENR'12 Ghardaïa, pp. 295 - 306, 2012.

[14] Qais Mohammed Aish, "Temperature Effect on Photovoltaic Modules Power Drop", AlKhwarizmi Engineering Journal, Vol.11, No.2, pp.62-73, 2015.

[15] Dominique Bonkoungou, Zacharie Koalaga, Donatien Njomo and François Zougmore," An Improved Numerical Approach for Photovoltaic Module Parameters Acquisition Based on Single-Diode Model" International Journal of Current Engineering and Technology, Vol.5, No.6, pp.37353742, 2015

[16] Mitulkumar R. Dave and K.C. Dave," Analysis of Boost Converter Using PI Control Algorithms", International Journal of Engineering Trends and Technology, Vol.3, Issue 2, pp.71-73, 2012.

[17] J.-P. Corriou, "Process Control", Springer International Publishing AG 2018.

[18] Ercan Kose*1, Aydin Muhurcu2," The Control of a Non-Linear Chaotic System Using Genetic and Particle Swarm Based On Optimization Algorithms", International Journal of Intelligent Systems and Applications in Engineering, Vol.4, Issue 4, pp. 145-149, 2016

[19] K. Mohamed Hussain, R. Allwyn Rajendran Zepherin, M. Shantha Kumar," Comparison of Tuning Methods of PID Controllers for FOPTD System", International Journal of Innovative Research in Electrical, Electronics, Instrumentation and Control Engineering,Vol. 2, Issue 3, pp. 1177-1180, 2014.

[20] Susmita Das, Ayan Chakraborty, Jayanta Kumar Ray, Soumyendu Bhattacharjee, Biswarup Neogi, " Study on Different 
Tuning Approach with Incorporation of Simulation Aspect for Z-N (ZieglerNichols) Rules" International Journal of Scientific and Research Publications, Volume 2, Issue 8, pp. 1-5, 2012.

[21] Sohaib Tahir, JieWang, Mazhar Hussain Baloch, Ghulam Sarwar Kaloi," Digital Control Techniques Based on Voltage Source Inverters in Renewable Energy Applications: A Review Electronics", 7, 18, 2018.

[22] Shravani Mathur, Vikas Kumar," Calculation of total Current harmonic distortion by PWM method for permanent magnet synchronous motors" International Journal of Engineering Research and Applications (IJERA), Vol. 3, Issue 3, pp.493-496, 2013.
[23] R. Senthilkumar, V. Manikandan," DESIGN OF FRACTIONAL ORDER PI Controller using Metaheuristic Algorithms applied to DC-DC Boost Converter- A Comparison", ARPN Journal of Engineering and Applied Sciences, Vol. 10, No. 11, pp. 4832-4837, 2015. 


\title{
تصميم ومحاكاة محول Boost ذي دائرة مغلقة مسيطر عليه بوساطة PI وعاكس ثلاثي الطور للنظبيقات الضوئية
}

\author{
رياض عدنان كاظم

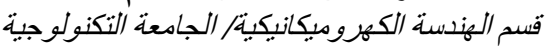 \\ البريد الالكتروني: alazizdl@gmail.com
}

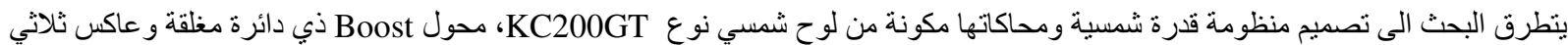

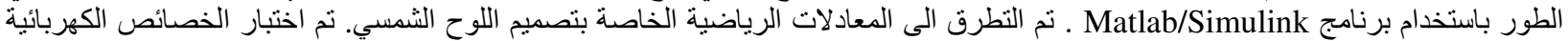

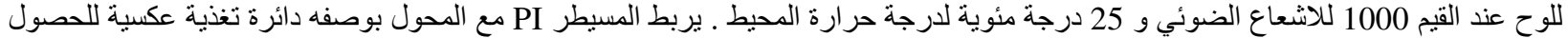

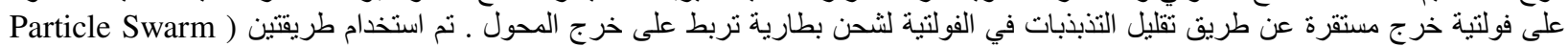

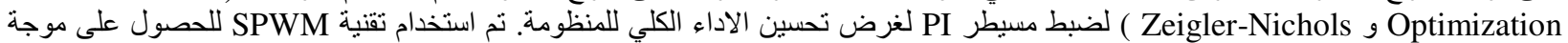

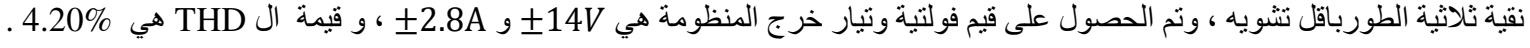

